\title{
Light as a Limiting Factor for Epilithic Algae in the Supralittoral Zone of Littoral Caves
}

\author{
Danielle Mayer*, Zvy Dubinsky and David Iluz \\ The Mina and Everard Goodman Faculty of Life Sciences, Bar-Ilan University, Ramat Gan, Israel
}

In a littoral cave system, abiotic environmental properties, such as the intensity and spectral distribution of light, often change going from the exterior to the interior part of the cave, filtering the light and thus creating a deep-sea irradiance setting for marine flora. In this mini-review, we suggest that the supralittoral zone in littoral caves might provide a sanctuary for mesophotic calcifying algae. These abiotic conditions offered an opportunity for normally deep-water mesophotic species to expand their range due to their competitive advantage over shallow, open-water species. Supralittoral calcifying algae are significant for marine biodiversity but are likely to be damaged in the future by ocean acidification. We have summarized important abiotic factors regarding algae settlement and succession processes in the supralittoral zone of littoral caves, including their photosynthetic pigments and habitat requirements. We describe their zonation according to irradiance, and review previous research on epilithic algal assemblages in littoral caves. Although we found a great deal of information on the algae of sea caves and littoral caves, no such information was published on the algae of the supralittoral zone of these caves. Nevertheless, some of the studies cited in this review have already set a good conceptual and methodological basis for the ecological research of the supralittoral algal flora of littoral caves. Universidade Federal Fluminense, Brazil Elena Stanca, University of Salento, Italy Keywords: calcifying algae, supralittoral zone, light spectrum, mesophotic algae, photosynthesis

*Correspondence: Danielle Mayer danielle.mayer@live.biu.ac.il

Specialty section: This article was submitted to Marine Ecosystem Ecology, a section of the journal Frontiers in Marine Science

Received: 27 October 2015 Accepted: 04 February 2016 Published: 19 February 2016

Citation:

Mayer D, Dubinsky Z and Iluz D (2016) Light as a Limiting Factor for Epilithic Algae in the Supralittoral Zone of

Coastal caves have different names according to their location or origin. Submerged or partly submerged caves are termed seaside or coastal caves. Caves or crevices located within the intertidal zone, with an opening at sea level, are littoral caves (Figure 1). Caves or crevices with an opening below sea level and entirely filled with seawater are submarine caves. A general name for submarine and littoral caves containing seawater is marine caves. Finally, caves associated with modern, historic, or prehistoric use by humans are grottos (Stock et al., 1986; Waterstrat et al., 2010). In this review, we discuss the supralittoral zone (above the intertidal zone) in littoral caves.

Littoral caves are fragile and peculiar environments listed in the EU Habitats Directive (Manconi et al., 2011). The supralittoral zone is never, or only very rarely, entirely immersed (Gili et al., 2014). Immersions occur only a few times a year, mainly during heavy storms with significantly high waves creating a high degree of humidity in the cave. Norton et al. (1971) suggested that continuous high humidity of the air assists algal settlement and success by reducing evaporation (Hauer et al., 2015). Hence, in supralittoral caves, the upper limit of algal settlement in the cave is often considerably above the water level (Figure 1).

Light is an important factor controlling the distribution of algae (Levring, 1947; Jerlov, 1957; Larkum et al., 1967; Hauer et al., 2015). In a study by DeNicola and Lellock (2015), 


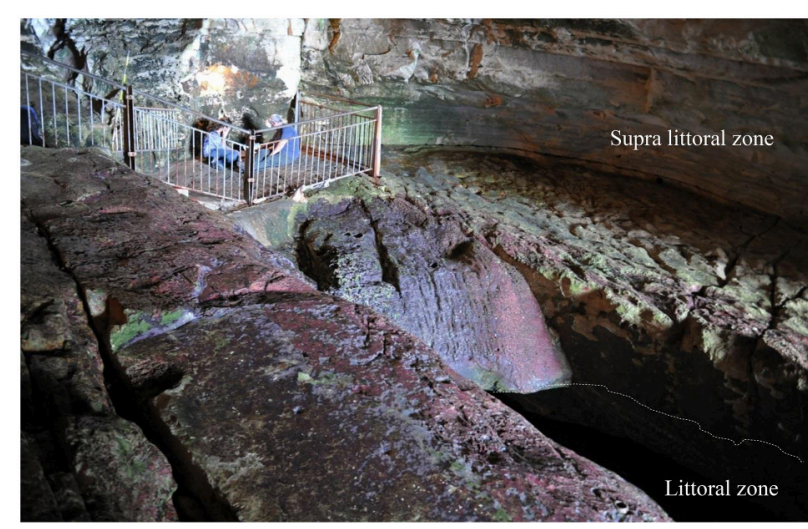

FIGURE 1 | Colorful epilithic algae in the supralittoral zone of the littoral cave system of Rosh HaNikra.

they explained the biomass of algal periphyton was mostly related to the extensive canopy cover (light), sometimes more than nutrient addition (Lowe et al., 1986; Hill and Knight, 1988; Zell and Hubbart, 2012). "Light" refers to electromagnetic radiation between 400 and $700 \mathrm{~nm}$ that is utilized in photosynthesis (Kirk, 1983); this range is defined as PAR, photosynthetically available radiation (Geider, 2013). As a result of absorption and scattering in the water column, the downward irradiance, $E_{d}$, of the light field diminishes exponentially with depth. The light decay coefficient varies from location to location, affecting the underwater light. To find the light decay coefficient, we use an equation by Kirk (1983):

$$
E_{d}(z)=E_{d}(0) e^{-k_{d} z}
$$

where $E_{d}(z)$ and $E_{d}(0)$ are the values of downwelling irradiance at $z \mathrm{~m}$ and just below the surface, respectively. $K_{d}$ is the vertical attenuation coefficient for downward irradiance and depends on wavelength as well, and $z$ is the water depth. In all waters, irradiance in the red waveband $(620-750 \mathrm{~nm})$ diminishes quite rapidly due to absorption by water molecules. In very clear waters, attenuation is lowest in the blue region $(450-495 \mathrm{~nm})$ and, with increasing depth, the underwater light becomes predominantly blue (Kirk, 1983). The underwater spectral light distribution allows algal divisions to thrive at certain water depths.

Another way to exploit the available light is by adaptations such as changing algal pigment composition and concentration (Dring, 1981; Kirk, 1983; Einav, 2007; Mulec et al., 2008). There are three chemically distinct groups of photosynthetic pigments: the chlorophylls, the carotenoids, and the biliproteins: phycoerythrin and phycocyanin. The photosynthetic pigments are presented in Table 1. The green algae, Chlorophyta, specialize in utilizing red light only present in the first few meters of the water column (Dring, 1981); the brown algae, Phaeophyta, are capable of using red and blue light, thriving in lower light than the Chlorophyta; and the red algae, Rhodophyta, can utilize the blue light and, thus, surpass the habitat range of the three and become dominant with depth in "blue waters" or other low-light environments (Dring, 1981). That property, namely, the absorption spectrum of phycoerythrin, the dominant red phycobiline (Table 1), is what is likely to allow red encrusting algae to become dominant in the blue enriched light in littoral caves (Figure 1). The low-light environment requires specialized strategies in order to survive (Stambler and Dubinsky, 2007; Dubinsky and Schofield, 2010). The amount and spectral composition of the ambient illumination changes markedly when entering littoral caves. Under such conditions, only species having morphological, genetic, physiological, and biochemical adaptations can survive and successfully compete. Vinogradova et al. (1998) found that in the deep parts of the cave, the biodiversity of phototrophic organisms is the lowest, with a decline in coccoid cyanobacteria and an increase in filamentous cyanobacteria as they progress deeper into the cave (Vinogradova et al., 1998). Similarly, Marti et al. (2004) compared the benthic assemblages of two Mediterranean submarine caves in Spain. They found that the algal coverage and the number of algal species decreased toward the internal (dark) recesses of the caves. In this study, Rhodophyta was the most common algae found, Phaeophyta was less common, and Chlorophyta was the rarest algal group. Mulec et al. (2008) observed epilithic algae in Slovenian caves and discovered that Cyanobacteria prevail in the algal community at cave entrances, colonizing into the deepest parts of the cave. In addition, they found that in order to capture as many available photons as possible at low irradiance, cells synthesize increased levels of accessory photosynthetic pigments such as Chl $b$, phycocyanin, and carotenoids (Table 1).

Giordano et al. (2000) agreed that algal cells living in caves have developed environmental adaptations by using efficiently low photon irradiance dosages, enabling them to have a better yield of available photons. After studying algae in Ukrainian caves, Vinogradova and Mikhailyuk (2009) concluded that light intensity is the main factor influencing the species distribution and zonation patterns of algal communities. Different adaptations in both photosynthetic prokaryotes and eukaryotic algae, predominantly from the divisions of Chlorophyta, Streptophyta, and Xanthophyta, help the algae successfully colonize the littoral caves (Vinogradova and Mikhailyuk, 2009). Coombes et al. (2015) studied the algal biogeomorphology of a marine karst cave at Puerto Princesa in the Philippines. They discovered a clear decline of algal abundance and diversity, as well as a decline of bio-erosion processes caused by microorganisms at a distance into the cave. Coombes et al. (2015) attributed these findings to light-induced gradients, and showed that the influence of light on phototrophs has consequences for the development of morphological features of limestone.

Marine photosynthesis and respiration are linked to calcification and $\mathrm{CaCO}_{3}$ dissolution, respectively, with significant effects on the alkalinity and $\mathrm{pH}$ of the oceans (Boyd et al., 2011), as can be seen by the following equation:

$$
\mathrm{Ca}^{2+}(\mathrm{aq})+2 \mathrm{HCO}_{3-}(\mathrm{aq}) \rightleftharpoons \mathrm{CaCO}_{3}(\mathrm{~s})+\mathrm{H}_{2} \mathrm{O}+\mathrm{CO}_{2}
$$

Various marine animals and algae have been producing $\mathrm{CaCO}_{3}$ at cellular sites of calcification ever since the 
TABLE 1 | Pigment distribution table of the different algal divisions.

\begin{tabular}{|c|c|c|c|c|c|c|c|c|}
\hline Division & Chl a & Chl $b$ & Chl $c$ & Chl d & Carotenes & Xanthophylls & Phycocyanin & Phycoerythrin \\
\hline Cyanophyta (Blue) & + & + & - & - & + & + & + & + \\
\hline Chlorophyta (Green) & + & + & - & - & + & + & - & - \\
\hline Rhodophyta (Red) & + & - & - & + & + & + & - & + \\
\hline Phaeophyta (Brown) & + & - & + & - & + & + & - & - \\
\hline Chrysophyta (Gold) & + & - & + & - & + & + & - & - \\
\hline Euglenophyta & + & + & - & - & + & + & - & - \\
\hline Charophyta & + & + & - & - & + & + & - & - \\
\hline Pyrrhophyta & + & - & + & - & + & + & - & - \\
\hline
\end{tabular}

Data were adapted from Levring (1947) and modified by Einav (2007), additional data was gathered from Mulec et al. (2008). Chl, chlorophyll. +, present -, absent.

Cambrian era (Brownlee and Taylor, 2002). The most abundant calcifying algae are the free-living, primarily marine, unicellular coccolithophores (Young and Henriksen, 2003). The coccolithophores occur in all the oceans of the world, creating monuments such as the Cliffs of Dover and most of the Mediterranean coastline (Lewin and Woodward, 2009; Stewart and Morhange, 2009; Gerovasileiou and Voultsiadou, 2012). Karstic processes in limestone may lead to a formation of littoral caves (Stock et al., 1986; Gerovasileiou and Voultsiadou, 2012). The littoral cave algal flora is dominated by coralline algae (family Corallinaceae, Rhodophyta), algae characterized by a hard thallus of calcareous deposits contained within the cell walls (Cusack et al., 2015). Coralline algae play an important role in marine ecosystems, providing reef framework, shore protection, and carbonate sediments in shallow water as well as being a source of food to surrounding herbivores (Martin et al., 2013; Coombes et al., 2015; Fabricius et al., 2015). Coralline algae contribute to the coastal carbon budget

\section{REFERENCES}

Boyd, P. W., Law, C. S., and Doney, S. C. (2011). Commentary: a climate change atlas for the ocean. Oceanography 24, 13-16. doi: 10.5670/oceanog.2011.42

Brownlee, C., and Taylor, A. R. (2002). "Algal calcification and silification," in Encyclopedia of Life Sciences (London: Macmillan Publishers Ltd.; Nature Publishing Group), 1-6.

Coombes, M. A., La Marca, E. C., Naylor, L. A., Piccini, L., De Waele, J., and Sauro, F. (2015). The influence of light attenuation on the biogeomorphology of a marine karst cave: a case study of Puerto Princesa Underground River, Palawan, the Philippines. Geomorphology 229, 125-133. doi: 10.1016/j.geomorph.2014.10.007

Cusack, M., Kamenos, N. A., Rollion-Bard, C., and Tricot, G. (2015). Red coralline algae assessed as marine pH proxies using B-11 MAS NMR. Sci. Rep. 5:8175. doi: $10.1038 /$ Srep 08175

DeNicola, D. M., and Lellock, A. J. (2015). Nutrient limitation of algal periphyton in streams along an acid mine drainage gradient. J. Phycol. 51, 54. doi: 10.1111/jpy.12315

Dring, M. J. (1981). Chromatic adaptation of photosynthesis in benthic marine algae - an examination of its ecological significance using a theoretical model. Limnol. Oceanogr. 26, 271-284. doi: 10.4319/lo.1981.26.2.0271

Dubinsky, Z., and Schofield, O. (2010). From the light to the darkness: thriving at the light extremes in the oceans. Hydrobiologia 639, 153-171. doi: 10.1007/s10750-009-0026-0

Geider, R. (2013). Algal Photosynthesis, Vol. 2. Springer Science and Business Media. in light of the twenty-first century ongoing process of ocean acidification (Field et al., 2014). The coralline algae are important to coastal biodiversity (Vinogradova et al., 1998; Mulec et al., 2008).

\section{AUTHOR CONTRIBUTIONS}

DM carried out the collection and summary of the articles and wrote the mini-review. $\mathrm{ZD}$ is responsible for critically revising the review, providing important intellectual content, and has approved this manuscript. DI has made a substantial contribution to the conception of this work, revised the work and approved this version.

\section{ACKNOWLEDGMENTS}

We thank Sharon Victor, Avrille Goldreich and Said Abu-Ghosh from Bar-Ilan University for critically reading the manuscript.

Einav, R. (2007). Seaweeds of the Eastern Mediterranean Coast. Koeltz Scientific Books, A.R.G. Gantner Verlag K.G.

Fabricius, K. E., Kluibenschedl, A., Harrington, L., Noonan, S., and De'Ath, G. (2015). In situ changes of tropical crustose coralline algae along carbon dioxide gradients. Sci. Rep. 5:9537. doi: 10.1038/srep09537

Field, C. B., Barros, V. R., Dokken, D. J., Mach, K. J., Mastrandrea, M. D., Bilir, T. E., et al. (eds.). (2014). "Summary for policymakers," in Climate Change 2014: Impacts, Adaptation, and Vulnerability. Part A: Global and Sectoral Aspects. Contribution of Working Group II to the Fifth Assessment Report of the Intergovernmental Panel on Climate Change. (Cambridge; New York, NY: Cambridge University Press).

Gerovasileiou, V., and Voultsiadou, E. (2012). Marine caves of the Mediterranean Sea: a sponge biodiversity reservoir within a biodiversity hotspot. PLoS ONE 7:e39873. doi: 10.1371/journal.pone.0039873

Gili, J.-M., Sardá, R., Madurell, T., and Rossi, S. (2014). “Zoobenthos," in The Mediterranean Sea: Its History and Present Challenges, eds S. Goffredo and Z. Dubinsky (Springer Science), 213-236.

Giordano, M., Mobili, F., Pezzoni, V., Hein, M. K., and Davis, J. S. (2000). Photosynthesis in the caves of Frasassi (Italy). Phycologia 39, 384-389. doi: 10.2216/i0031-8884-39-5-384.1

Hauer, T., Muhlsteinová, R., Bohunická, M., Kaštovsky, J., and Mares, J. (2015). Diversity of cyanobacteria on rock surfaces. Biodivers. Conserv. 24, 759-779. doi: 10.1007/s10531-015-0890-z

Hill, W. R., and Knight, A. W. (1988). Nutrient and light limitation of algae in two northern California streams. J. Phycol. 24, 125-132. doi: 10.1111/j.15298817.1988.tb04225.x 
Jerlov, N. G. (1957). Optical Studies of Ocean Waters (No. 1). Goteborg: Elanders Boktr.

Kirk, J. T. O. (1983). Light and Photosynthesis in Aquatic Ecosystems. Cambridge; New York, NY: Cambridge University Press.

Larkum, A. W. D., Drew, E. A., and Crossett, R. N. (1967). Vertical distribution of attached marine algae in Malta. J. Ecol. 55, 361-371. doi: 10.2307/2257881

Levring, T. (1947). Submarine Daylight and Photosynthesis of Marine Algae (online). Göteborgs K. Vetenskaps o. Vitterhets Samhäll. Handl. Ser. B, 5 , No. 6 .

Lewin, J., and Woodward, J. C. 2009). "Karst geomorphology and environmental change," in The Physical Geography of the Mediterranean, ed J. C. Woodward (Oxford: Oxford University Press), 287-317.

Lowe, R. L., Golladay, S. W., and Webster, J. R. (1986). Periphyton response to nutrient manipulation in streams draining clearcut and forested watersheds. J. North Am. Benthol. Soc. 5, 221-229. doi: 10.2307/ 1467709

Manconi, R., Cadeddu, B., Pansini, M., Pronzato, R., and Ledda, F. D. (2011). Biodiversity of Sardinian marine caves: sponge fauna. Biol. Mar. Med. 18, 258-259.

Marti, R., Uriz, M. J., Ballesteros, E., and Turon, X. (2004). Benthic assemblages in two Mediterranean caves: species diversity and coverage as a function of ablotic parameters and geographic distance. J. Mar. Biol. Assn. U.K. 84, 557-572. doi: $10.1017 /$ S0025315404009567h

Martin, S., Charnoz, A., and Gattuso, J. P. (2013). Photosynthesis, respiration and calcification in the Mediterranean crustose coralline alga Lithophyllum cabiochae (Corallinales, Rhodophyta). Eur. J. Phycol. 48, 163-172. doi: 10.1080/09670262.2013.786790

Mulec, J., Kosi, G., and Vrhovšek, D. (2008). Characterization of cave aerophytic algal communities and effects of irradiance levels on production of pigments. J. Cave Karst Studies 70, 3-12.

Norton, T. A., Ebling, F. J., and Kitching, J. A. (1971). "Light and the distribution of organisms in a sea cave," in Fourth European Marine Biology Symposium, ed D. J. Crisp (Cambridge: Cambridge University Press), 409-432.

Stambler, N., and Dubinsky, Z. (2007). "Marine phototrophs in the twilight zone," in Algae and Cyanobacteria in Extreme Environments. Series: Cellular Origin, Life in Extreme Habitats and Astrobiology, Vol. 11, ed J. Seckbach (Springer) 79-97.
Stewart, I. S., and Morhange, C. (2009). "Coastal geomorphology and sea-level change," in The Physical Geography of the Mediterranean, ed J. C. Woodward (Oxford: Oxford University Press), 385-413.

Stock, J. H., Iliffe, T. M., and Williams, D. (1986). The concept anchialine reconsidered. Stygologia 2, 90-92.

Vinogradova, O. N., Kovalenko, O. V., Wasser, S. P., Nevo, E., and WeinsteinEvron, M. (1998). Species diversity gradient to darkness stress in blue-green algae/cyanobacteria: a microscale test in a prehistoric cave, Mount Carmel, Israel. Israel J. Plant Sci. 46, 229-238. doi: 10.1080/07929978.1998.10676732

Vinogradova, O. N., and Mikhailyuk, T. I. (2009). Algal flora of the caves and grottoes of the National Nature Park "Podilsky Tovtry" (Ukraine). Int. J. Algae 11, 289-304. doi: 10.1615/InterJAlgae.v11.i3.80

Waterstrat, W. J., Mylroie, J. E., Owen, A. M., and Mylroie, J. R. (2010). Coastal caves in Bahamian eolian calcarenites: differentiating between sea caves and flank margin caves using quantitative morphology. J. Cave Karst Studies 72, 61-74. doi: 10.4311/jcks2009es0086

Young, J. R., and Henriksen, K. (2003). "Biomineralization within vesicles: the calcite of coccoliths," in Reviews in Mineralogy and Geochemistry: Biomineralization, Vol. 54, eds P. M. Dove, J. J. De Yoreo, and S. Weiner (Washington, DC: Mineralogical Society of America), Chapter 7, 189-216.

Zell, C., and Hubbart, J. A. (2012). An evaluation of light intensity functions for determination of shaded reference stream metabolism. J. Environ. Manage. 97, 69. doi: 10.1016/j.jenvman.2011.12.006

Conflict of Interest Statement: The authors declare that the research was conducted in the absence of any commercial or financial relationships that could be construed as a potential conflict of interest.

The reviewer, ES, and handling Editor declared their shared affiliation, and the handling Editor states that the process nevertheless met the standards of a fair and objective review.

Copyright (c) 2016 Mayer, Dubinsky and Iluz. This is an open-access article distributed under the terms of the Creative Commons Attribution License (CC BY). The use, distribution or reproduction in other forums is permitted, provided the original author(s) or licensor are credited and that the original publication in this journal is cited, in accordance with accepted academic practice. No use, distribution or reproduction is permitted which does not comply with these terms. 